\title{
Influence of Heating Time of Shea Nuts (vitellariaparadoxa) on Some Chemical Properties of Shea Butter
}

\author{
V. T. Tame ${ }^{1 *}$, I. Hassan ${ }^{2}$, D. T. Gungula1 \\ ${ }^{1}$ Department of Crop Production and Horticulture, Modibbo Adama University of Technology, Yola, Nigeria \\ ${ }^{2}$ Department of Agricultural Technology, College of Agriculture Ganye, Adamawa, Nigeria \\ Email: ${ }^{\text {tammeval@gmail.com }}$
}

Received 11 July 2015; accepted 21 August 2015; published 25 August 2015

\section{Abstract}

The experiment was conducted in the laboratories of the Departments of Chemistry and Animal Health and Production Technology, Adamawa State University, Mubi, Nigeria. The experiment was replicated three times in a Randomized Complete Block Design (RCBD) and consisted of six heating time 30, 60 and 120 minutes boiling, 30, 60 and 120 minutes roasting and one control. Data were collected on acid value, free fatty acid, iodine value, peroxide value, saponification value and unsaponifiable matter. The data collected were analyzed statistically using Generalized Linear Model (GLM) procedure of statistical analysis system (SAS). The means that were significantly different were separated using Least Significant Difference (LSD). The results showed that there were highly significant differences $(P \leq 0.01)$ among the treatments. The highest Acid Value (AV) of 3.53 and 3.64 were recorded by heating time at 120 minutes of boiling and 120 minutes of roasting. Heating time at 30 minutes of boiling, 30 minutes roasting, 60 minutes boiling and 60 minutes roasting recorded lower Free Fatty Acid (FFA) values of 1.52, 1.55, 1.57 and 1.58, respectively. Heating time at 60 minutes of roasting and 60 minutes of boiling recorded the highest Iodine value (IV) of 43.80 and 43.53 , respectively. Based on the results of this study, it can be concluded that heating time of 30 or 60 minutes by boiling or roasting are better than longer heating times for Shea butter extraction.

\section{Keywords}

Heating Time, Shea Nut, Shea Butter, Chemical Properties

\section{Introduction}

The shea butter fat/oil is commonly called "maikadanya" in the Northern Nigeria. The fat was extracted from kernels of the shea tree which is in the sapotacea family under the accepted name Vitellariaparadoxa Van Gaertn, which is formally called Butyrospermum paradoxum Hepper [1]. The shea butter is good as table oil;

\footnotetext{
"Corresponding author.
}

How to cite this paper: Tame, V.T, Hassan, I. and Gungula, D.T. (2015) Influence of Heating Time of Shea Nuts (vitellariaparadoxa) on Some Chemical Properties of Shea Butter. World Journal of Engineering and Technology, 3, 13-18. 
while the residual product (shea cake) is a good ingredient for livestock feed formulation as well as for the treatment of skin diseases including leprosy and other ailments [2]. Shea butter has many industrial uses that include: soap making, cosmetics, lubricants and paints. According to Russo and Etherington [3], shea butter is ideal for use as a raw material for oil, margarine, cosmetics, soap, detergents and candles. Furthermore, shea butter has found primary market importance as a substitute for cocoa butter in the chocolate and confectionery industry.

The enzyme that is responsible for the buildup of free fatty acids (FFA) is inactivated through sun drying and roasting of the kernels. This also prevents the growth of fungus such as Aspergillus specie (American Shea Butter Institute [ASBI], 2004). The rural village shea butter processors, after de-husking the shea nuts, roast the kernels or dry them from morning till evening for more than 2 weeks. The kernels become over heated and black as a result, dark oil is produced from the kernels. According to ASBI [4], sun drying and roasting process should be controlled such that the kernels are not over heated and become black as these lead to increased FFA, peroxide value (PV) and dark oil or butter.

The postharvest heat treatment of vegetable oil seeds influences their physicochemical quality. [5] noted that blanching the shea nuts improves shea butter quality, while [6] underlined that sensorial characteristics of shea and cocoa butters were linked to the kernel roasting time. Also [1] and [7] reported that the drying time and roasting time of shea kernel affected the physicochemical characteristics of shea butter. [8] reported that some chemical components of shea butter depended upon how the shea kernel and shea butter were processed.

The amount of heating time taken to treat shea nut creates some problems in the chemical characteristics of the traditional shea butter [1]. In order to produce good quality shea butter, the amount of heating time taken to treat the nuts needs to be determined. Hence, this study was carried out with the aim to determine heating times on some chemical characteristics of traditional shea butters

\section{Materials and Methods}

The postharvest experiment of heating time of shea nuts and the butter extraction were traditionally carried out and the laboratory experiment was carried out in the laboratories of the Departments of Chemistry and Animal Health and Production Technology, Adamawa State University, Mubi, Nigeria. Shea fruit were harvested from the bush in Hong Local Government Area (LGA) of Adamawa State in August 2010. This was because of the availability of shea trees that fruited in this area during the study year.

Matured ripened shea fruit that fell under their own weight as a result of feeding by birds to the ground were gathered under several shea trees. The fruits were fermented by keeping them in an air tight container for two days and depulped by washing in clean water. The depulped shea nuts were divided into seven equal portions. Each of the portions was again divided into 3 sub samples. Sub samples of the first, second and third portions were separately subjected to heat treatment for 30, 60 and 120 minutes of boiling, respectively. Sub samples of the fourth, fifth and sixth portions were also separately subjected to heat treatment for 30, 60 and 120 minutes of roasting, respectively. The sub-samples of the last portion were left fresh without boiling or roasting and served as the control treatment. The heat treated samples were dried for three days and de-husked to obtain the kernels, while the control samples were de-husked fresh without drying. The kernels were brushed or squeezed against each other to reduce the brown substances on them. The kernels were crushed and ground before the extraction process.

The crushed sub samples of shea kernels resulting from each of the seven portions were milled into powdered material separately. A sample of $350 \mathrm{~g}$ was obtained from one of the powdered sub-sample parts and mix with water into paste. The paste was poured into a clean washed pot and placed on the fire. Two equal volumes of water as of the paste were added and stirred very well. The fire was allowed to burn gently under the pot. The paste boiled until water evaporated from the paste and oil raised from the paste to the surface while the residues settle at the bottom of the pot. The oil was decanted and filtered using sieve to remove impurities. The butter was cooled, measured and the value was recorded. The oil was poured into plastic container, covered and labeled. These extraction processes were followed for all the sub-samples and were taken to the laboratory for analysis.

Randomized Complete Block Design (RCBD) was used for the experiment. The experiment was replicated three times. The factor in the experiment consisted of six heating times $(30,60,120)$ minutes of boiling, $(30,60$ and 120) minutes of roasting and one control (that is fresh without boiling or roasting) treatments. 
Samples of shea butter were obtained and packed in plastic containers, labeled and taken to the laboratory and stored under room temperature. The samples were labeled following the heating times applied during shea nuts treatment. The shea butter samples were characterized.

All chemicals and reagents used during the characterization of the Shea butter were of analytical grade. For the other specific preparations, distilled water was used. The tests were performed in triplicates and their means were used.

1) Acid value: The acid value was determined following the procedure described by [10]. This was done by mixing $25 \mathrm{ml}$ diethyl ether with $25 \mathrm{ml}$ alcohol and $1 \mathrm{ml}$ phenolphthalein solution (1\%) and carefully neutralized with $0.1 \mathrm{M} \mathrm{NaOH}$. A sample (2 g) of shea butter was melted and dissolved in the mixed neutral solution and titrated with aqueous $0.1 \mathrm{M} \mathrm{NaOH}$ until a pink colour which persisted for $15 \mathrm{sec}$ was obtained. The acid value was calculated using the formula:

$$
\text { Acid valu }=\frac{\text { Titre }(\mathrm{ml}) \times 5.61}{\text { Weight of shea butter sample used }}
$$

2) Free fatty acid: The free fatty acid of the shea butter was determined according to the method described by Association of Official Analytical Chemists (AOAC) [11]. It was done by adding $1 \mathrm{ml}$ of melted shea butter to $3 \mathrm{ml}$ of neutral ethanol and warmed for two minutes after which one drop of phenolphthalein indicator was added and titrated with $0.1 \mathrm{M}(\mathrm{NaOH})$ and a base using burette until a final colour which persisted for 1 minute was obtained. The free fatty acid was calculated using the formula:

$$
\text { Free fatty acid }=\frac{\text { Titre }(\mathrm{ml}) \times 28.2}{\text { Weight of shea butter sample used }}
$$

3) Iodine value: The iodine value of shea butter was determined using the method described by [10]. This was done by weighing $0.5 \mathrm{~g}$ of shea butter sampled into $250 \mathrm{ml}$ capacity glass stopped bottle and $10 \mathrm{ml}$ of carbon tetrachloride was added and dissolved after which $25 \mathrm{ml}$ of Wiji's solution was also added. It was allowed to stand for 30 minutes in the dark after which $15 \mathrm{ml}$ of potassium iodide solution (1\%) and $100 \mathrm{ml}$ of water were added, mixed and titrated with $0.1 \mathrm{M}$ thiosulphate using starch as an indicator (titration $=\mathrm{aml}$ ). A blank titration was carried out at the same time with $10 \mathrm{ml}$ carbon tetrachloride (titration $=$ bml). The iodine value was then calculated using the formula:

$$
\text { Iodine value }=\frac{(b-a) \times 1.269}{\text { Weight of shea butter sample used }}
$$

where:

$a=$ titration value;

$b=$ blank titration value.

4) Peroxide value: Peroxide value was determined using the procedure reported by [10]. It was done by weighing $1 \mathrm{~g}$ of melted shea butter sample into a boiling tube followed by adding $1 \mathrm{~g}$ of powdered potassium iodide and $2 \mathrm{ml}$ of solvent mixture (two volume of glacial acetic acid and 1volume of chloroform). The tube was placed in boiling water and allowed to boil for 30 seconds and then vigorously for another 30 seconds. The content of the tube was poured immediately into a flask containing $20 \mathrm{ml}$ of potassium iodide solution (5\%) and the tube was washed out twice with $25 \mathrm{ml}$ of water and titrated with $0.002 \mathrm{M}$ sodium thiosulphate solution using starch (titration $=V 1$ ). A blank titration was also carried out at the same time (titration $=V 2$ ). Peroxide value was calculated using the formula:

$$
\text { Peroxide value }=\frac{(V 2-V 1)}{\text { Weight of shea butter sample used }}
$$

5) Saponification value: Saponification value was calculated following the procedure reported by [10]. It was done by weighing $2 \mathrm{~g}$ of shea butter oil into a conical flask and $25 \mathrm{ml}$ of alcoholic potassium hydroxide solution was added and attached to a reflux condenser. The flask was heated in a boiling water for 1 hour and phenolphthalein (1\%) solution was added and titrated with $0.5 \mathrm{M}$ hydrochloric acid (titration = aml). A blank titration was simultaneously carried out (titration $=\mathrm{bml})$. Saponification value was calculated using the for- 
mula:

$$
\text { Saponification value }=\frac{(b-a) \times 28.05}{\text { Weight of shea butter sample used }}
$$

where:

$a=$ titration value;

$b=$ blank titration value.

6) Unsaponifiable matter: The unsaponifiable matter was determined following the procedure reported by [10]. This was done after the titration of a saponification value by making neutralized liquid alkaline with $1 \mathrm{M}$ of aqueous $3 \mathrm{M}$ potassium hydroxide solution and transferred to a separator and then washed with water. The solution was extracted while still warm three times with $50 \mathrm{ml}$ of quantity of diethyl ether and each extract was poured into another separator containing $20 \mathrm{ml}$ water. After the third extract was added, the combined ether extract were shaken with the first $20 \mathrm{ml}$ of the wash water and then vigorously with the two further 20 $\mathrm{ml}$ quantities. The ether extract was washed twice with $20 \mathrm{ml}$ of aqueous $0.5 \mathrm{M}$ potassium hydroxide solution and twice with $20 \mathrm{ml}$ quantities until the washed water was no more alkaline to phenolphthalein. The ether extract was poured into weighed flask and the solvent was evaporated and the residue dried at $80^{\circ} \mathrm{C}$ and weighed until a constant weight was obtained and recorded.

\section{Results}

The result showed that there were highly significant $(\mathrm{P} \leq 0.01)$ differences among the various heating time on all the parameters measured. The mean effect of heating times of shea nuts on the chemical properties of shea butter are presented in Table 1. The result showed that, short heating time improved quality of shea butter better than long heating time when compared to the control treatment. Heating time at 30 minutes of boiling and 30 minutes of roasting recorded the lower acid values(AV) (3.03) and (3.05), while heating time at 60 minutes of boiling and 60 minutes of roasting recorded AV of 3.13 and 3.15, respectively. The result also showed that the highest $\mathrm{AV}$ of 3.53 and 3.64 were recorded by heating time at 120 minutes of boiling and 120 minutes of roasting. The lowest $\mathrm{AV}$ value of 2.92 was recorded by control treatment.

Concerning the free fatty acid (FFA), heating time at 30 minutes boiling, 30 minutes roasting, 60 minutes boiling and 60 minutes roasting recorded lower FFA values of 1.52, 1.55, 1.57 and 1.58, respectively. Highest FFA values (1.83 and 1.80) were recorded at 120 minutes boiling and 120 minutes roasting, respectively. The control treatment has the lowest FFA value (1.47).

Heating time at 60 minutes of roasting and 60 minutes of boiling recorded the highest Iodine value (IV) of 43.80 and 43.53, respectively. The heating time at 120 minutes of roasting and 120 minutes of boiling followed with values of 42.94 and 42.04 , respectively. The heating time at 30 minutes of boiling and 30 minutes of roasting

Table 1. Mean effect of heating time of shea nuts on the chemical properties of shea butter.

\begin{tabular}{ccccccc}
\hline Treatment & AV (mgKOH/g) & $\begin{array}{c}\text { FFA } \\
(\mathrm{mgKOH} / \mathrm{g})\end{array}$ & IV (wij) & PV (meq/kg) & SV (mgKOH/g) & $\begin{array}{c}\text { USM } \\
(\mathrm{mgKOH} / \mathrm{g})\end{array}$ \\
\hline T1 & 3.03 & 1.52 & 42.55 & 11.38 & 196.97 & 6.22 \\
T2 & 3.05 & 1.55 & 42.58 & 11.42 & 196.96 & 6.15 \\
T3 & 3.13 & 1.57 & 43.53 & 11.53 & 198.43 & 6.33 \\
T4 & 3.15 & 1.58 & 43.80 & 11.55 & 198.55 & 6.33 \\
T5 & 3.53 & 1.80 & 42.94 & 13.45 & 196.98 & 6.13 \\
T6 & 3.64 & 1.83 & 42.94 & 13.48 & 196.05 & 6.07 \\
T7 & 2.92 & 1.47 & 21.14 & 11.27 & 98.45 & 5.98 \\
Mean & 3.21 & 1.62 & 39.92 & 12.01 & 183.34 & 6.17 \\
P of F & 0.001 & 0.001 & 0.001 & 0.001 & 0.001 & 0.001 \\
LSD & 0.03 & 0.03 & 0.04 & 0.05 & 0.01 & 0.32 \\
\hline
\end{tabular}

T1: 30 min. boiling; T2: 30 min. roasting; T3: 60 min. boiling; T4: 60 min. of roasting; T5: 120 min. boiling; T6: 120 min. roasting; T7: control 
(without boiling and roasting); P of F = Probability level; LSD: List significant Difference; AV: acid value; FFA: free fatty acid; IV: iodine value; PV: peroxide value; SV: saponification value; USM: unsaponifiable matter.

recorded iodine values of 42.55 and 42.78 , respectively. The lowest IV was recorded by the control treatment with value of 21.14 which differed from all the rest of the treatments on IV.

On the Peroxide value (PV) heating time at 120 minutes of roasting recorded the highest PV of 13.48 followed by heating time at 120 minutes of boiling with the value of 13.45 . Heating time at 30 minutes of boiling, 30 minutes of roasting, 60 minutes of boiling and 60 minutes of roasting recorded PV values of 11.38, 11.42, 11.53 and 11.55, respectively. The lowest best PV was recorded by the control treatment which had 11.27 value.

Concerning the saponification (SV), heating time at 60 minutes of roasting and 60 minutes of boiling recorded the highest best values (198.55 and 198.43), respectively. Heating at 120 minutes of boiling, 30 minutes of boiling, 30 minutes of roasting and 120 minutes of roasting followed with the values of SV $(196.98,196.97,196.96$ and 196.045), respectively. The lowest SV value (96.45) was recorded by the control treatment.

Similarly, on unsaponifiable matters (USM), heating time at 60 minutes of boiling and 60 minute of roasting recorded the highest values (6.33) each, followed by heating time at 30 minutes of boiling, 30 minutes of roasting, 120 minutes of boiling and 120 minutes of roasting with the USM values $(6.217,6.15$, 6.13 and 6.07), respectively. The control treatment recorded the lowest value of 5.98 which is significantly lower than the rest of the treatments on unsaponifiable matter.

\section{Discussion}

For the properties of acid and free fatty acid, the values increased showing reduction in the quality of shea butter. According to [12] loss of moisture content occurs as a result of dehydration and drying of carbohydrate and oil content during heat treatment of oil seed and the formation of free fatty acid in oil seed start with the thermal pre-treatment of the seeds prior to the oil extraction. Lower values of these properties were observed at short heating time. The rates of acid formation were higher when the heating time of shea nut was increased from 60 minutes of boiling and roasting to 120 minutes of boiling and roasting.

Shea butter value for iodine, saponification and unsaponifiable matter increased as the heating time increased. The values of these properties decreased with further increase in the heating time above 60 minutes of boiling or roasting to 120 minutes of boiling or roasting. The decrease observed in the iodine value, saponification and unsaponifiable matter after 60 minutes of boiling or roasting shows that heating shea nuts beyond 60 minutes of boiling or roasting is not appropriate for production of good quality of shea butter.

\section{Conclusion}

Based on the results obtained from the study, it can be concluded that short heating time of shea nut at 30 , 60 minutes of boiling and 30, 60 minutes of roasting improved the quality of shea butter better for all the properties measured on shea butter. Long heating time beyond 60 minutes of boiling and roasting reduced the quality of shea butter for all the properties measured except moisture content.

\section{References}

[1] Kepsue, C., Bup, N.D., Tchiegang, C., Abi, C.F., Jannot, Y., Parmentier, M. and Puiggali, J.R. (2005) Air Drying of Butyruspermum parkii Kernels. Proceeding of the 14th International Symposium, Sao Paulo, 2051-2058.

[2] Ogbonnaya, C. and Adgidzi, P.P. (2008) Evaluation of Some Physicochemical Properties of Shea Butter (Butyrospermum paradoxum) Related to Its Value for Food and Industrial utilization. International Journal for Postharvest Technology, 1, 320-326. http://dx.doi.org/10.1504/IJPTI.2008.021466

[3] Russo, L. and Etherington, T. (2001) Non Wood News. An Information Bulletin on Non Wood Forest Products, 8, 38-39.

[4] American Shea Butter Institute (ASBI) (2004) Twenty One Reasons to Use Shea Butters. American Shea Butter Institute, Columbus, GA 31908-7906, USA.

[5] Lovette, P. (2004) Research and Development of Premium Quality Shea Butter for Production in Northern Ghana. Phase Three. March-August 2003. Technoserve Inc., Ghana.

[6] Sanz, C., Ansorena, D., Bello, J. and Cid, C. (2001) Optimizing Headspace Temperature and Time Sampling for Identification of Volatile Compounds in Ground Roasted Arabica Coffee. Journal of Agriculture and Food Chimistry, 49, 1364-1369. http://dx.doi.org/10.1021/jf001100r 
[7] Womeni, H.M., Ndjouekeu, R., Kepsue, C., Fanni, J.J. and Parmentier, M. (2006) Application du procédé séchagefriture aux amandes de karité: influence sur les indices chimiques de qualité et les propriétés de fusion du beurre. Oleagineux Corps Gras Lipides, 13, 297:302.

[8] Womeni, H.M., Kanga, R., Tchiegang, C. and Kepsue, C. (2002) Influence de humidity sur L "extraction de karite: Influence du Sechage des Amandeset de la n Technique d' extraction. La rivisita Delle Sobstance Grasses, LXXIX, 3338.

[9] Addaquay, J. (2004) Economic and Technology Assessment of West African-Based Shea.

[10] Gregory, I.O. (2005) Food Analysis and Instrument. Theory and Practice. Naphtali Prints, A Division of HG Support Nigeria, 103-106.

[11] Association of Official Analytical Chemists (AOAC) (1984) Official Methods of Analysis. 17th Edition, Association of Official Analytical Chemists, Washington DC.

[12] Asuquo, J.E. (2008) Studies on the Adsorption of Some Selected Metallic Soaps on the Hermatite. Ph.D. Dissertation, University of Port Harcourt, Nigeria. 